\section{Health related quality of life of the geriatric population \\ living in rural areas of West Tripura district of India: a cross-sectional study}

\author{
Arpita Debnath, Himadri Bhattacharjya \\ Department of Community Medicine, \\ Agartala Government Medical College, \\ Agartala, Tripura, India
}

\section{Abstract \\ Growing life expectancy is challenging} the quality of health care for elderly. Information regarding health related quality of life (QOL) may help policy makers to design need based health programs for this population. The objectives of this study were to estimate health related QOL of the geriatric population living in rural areas of West Tripura district and to compare it between ethnic and non-ethnic populations in respect to important domains. This community based cross-sectional study was conducted during $1^{\text {st }}$ February 2019 to $31^{\text {st }}$ March 2020 among 225 geriatric subjects of rural West Tripura district chosen by multistage sampling. World Health Organization's QOL-BREF scale was used for data collection. Among the study population $46.2 \%$ had overall good health related QOL. About 52.9\% had good QOL in environment and $37.3 \%$ had good QOL in social relationship domains. Marginally higher proportion of the subjects from ethnic origin had better QOL than the non-ethnic but it was not significant. Higher proportion of the Muslim subjects had better QOL than the rest, but it was also not significant. Bivariate analysis showed significant associations of QOL with age, sex, literacy, financial condition, socioeconomic status and type of family. Multivariate analysis identified male sex, younger age and living with spouse as significant predictors of good QOL. Overall health related QOL of the geriatric people living in rural areas of West Tripura district is poor but younger male subjects, of ethnic origin and living with spouse may enjoy relatively better QOL.

\section{Introduction}

Quality of life (QOL) is defined by the World Health Organization (WHO) as 'the condition of life resulting from the combination of the effects of the complete range of factors such as those determining health, happiness, education, social and intellectual attainments, freedom of action, justice and freedom of expression'. ${ }^{1}$

All the aspects of health status, lifestyle, life satisfaction, mental state and well-being together reflect the multidimensional nature of QOL. ${ }^{2}$ As life expectancy keeps on rising, the biggest challenge to public health remains the improvement in the quality of life during the later phage of life. ${ }^{3}$ In old age, there is increased risk of morbidity due to limitations of movements due to pain and discomfort and this is exacerbated by financial burden and difficulties in accessing health care services. Geriatric health care services being relatively newer discipline in the developing world, modern physicians need to be sensitized regarding the clinical and social implications of ageing.

The medical and psycho-social challenges being faced by the elderly should be highlighted and strategies for bringing about an improvement in their quality of life should be implemented. ${ }^{4}$ In India, the share of population over the age of $60 \mathrm{yr}$. is $8.6 \%$, which will increase to $19 \%$ in $2050 .{ }^{5}$ According to census 2011, there were nearly 104 million elderly (aged 60 yr.) in India. ${ }^{6}$

Tripura has the highest proportion of elderly population $(7.9 \%)$ among all the North-Eastern states of India, which is 206 per thousand general populations in the rural areas. ${ }^{7}$ Though there are many global and Indian studies regarding assessment of QOL among geriatric population, limited studies have been conducted in North-East India and the scenario in Tripura is further unexplored. In this context the present study was designed to estimate the health-related QOL among geriatric population living in rural areas of West Tripura district of India and determine the associations of various factors with their QOL.

\section{Materials and Methods}

This community based cross-sectional study was conducted during $1^{\text {st }}$ February 2019 to $31^{\text {st }}$ March 2020 in the rural areas of West Tripura district. A predesigned, pretested and structured interview schedule containing socio-demographic information and WHOQOL-BREF scale were used for collecting data.

Minimum sample size requirement for this study was calculated using the formula: $\mathrm{n}=\mathrm{Z}^{2}{ }_{\alpha / 2} \sigma^{2} / \mathrm{d}^{2}{ }^{8}$ Where, $\mathrm{n}=$ sample size; $\mathrm{O}=$ standard deviation of overall quality of life (10.21 in this study). ${ }^{9} \mathrm{Z}_{\alpha / 2=} 1.96$ (value of the standard normal deviate at 5\% level of significance), $\mathrm{d}=$ absolute precision $=2$ and additional $10 \%$ for the incomplete respons-
Correspondence: Arpita Debnath, Department of Community Medicine, Agartala Government Medical College, P. O. Kunjavan, Pin: 799006, Agartala, Tripura, India.

E-mail: debnatharpita1987@gmail.com

Key words: Quality of life; geriatric; Tripura; rural.

Acknowledgements: the authors would like to express their gratitude to all study participants for participating in this study and their cooperation during data collection. Authors are also thankful to the ASHA workers for their assistance during data collection.

Contributions: $\mathrm{AD}$ has prepared the study protocol, collected data after obtaining approval from Institutional Ethics

Committee, performed data entry and analysis. She has also drafted the manuscript. HB has guided the first author in preparing the study protocol, collecting data and data entry in computer. Also analyzed data and scrutinized the manuscript.

Conflict of interest: the authors declare no potential conflict of interest.

Ethics approval: this study was approved by the institutional Ethics Committee of Agartala Government Medical College.

Place of conducting the study: this study was conducted among the geriatric population living in rural areas of West Tripura district of Northeast India during $1^{\text {st }}$ February 2019 to $31^{\text {st }}$ March 2020

Received for publication: 13 August 2021. Revision received: 17 November 2021.

Accepted for publication: 3 December 2021.

This work is licensed under a Creative Commons Attribution-NonCommercial 4.0 International License (CC BY-NC 4.0).

${ }^{\circ}$ Copyright: the Author(s), 2021

Licensee PAGEPress, Italy

Geriatric Care 2021; 7:10036

doi:10.4081/gc.2021.10036

es was considered for this study. Thus, final sample size was calculated to be 220 geriatric subjects.

Multistage random sampling was adopted for selecting the study subjects. West Tripura district has 9 blocks. Blockwise list of sub-centers was obtained from the Directorate of Family Welfare and Preventive Medicine and used to construct sampling frame. One sub-center from each of these blocks was selected by simple random sampling without replacement. Thus 9 sub centers were selected from 9 blocks. Households having geriatric subjects were identified by studying the family registers 
maintained at different sub-centers and subcenter level sampling frames were prepared. Equal number of study subjects was planned to be selected from each sub-center. Thus, $(220 \div 9)=24.44 \sim 25$ geriatric individuals were selected from each sub-center area by simple random sampling without replacement. Only one geriatric individual from each of these identified houses were selected by lottery and thus total 225 geriatric individuals were enrolled in this study.

WHOQOL-BREF ${ }^{10}$ questionnaire considered 4 domains namely: physical health, psychological, social relationships and environmental domain with 26 questions. Likert's 5-points scale in the positive direction was used for rating each domain. As per the WHO guidelines scores for each domain was calculated by adding the scores of all items of that domain and transforming them into a value ranging from 4-20. Overall total and mean score of all the domains were calculated. The mean score for overall quality of life was considered as cut-off. Those who scored equal, or more than the mean score were considered as having good QOL and those scored below the mean were considered as having poor QOL.

Subjects aged $\geq 60$ years were considered as geriatric subjects and those residing in block or village panchayet areas were considered as rural subjects. Subjects belonging to the tribal communities were considered as ethnic. Socio economic status of the study subjects was determined using BG Prasad's socioeconomic classification scale 2019. Subjects having no formal schooling were considered as illiterate, schooling at to any level up to class $\mathrm{V}$ as primary, any level between class V to XII as secondary and beyond class XII were considered as graduate and above.

Data were analyzed using SPSS-25 for windows (IBM Corp. Released 2017; IBM SPSS Statistics for Windows, Version 25.0. Armonk, NY: IBM Corp.). For summarizing the qualitative data frequency and percentages and for quantitative data mean and SD were used. Chi-square statistic was applied to test the associations of QOL with various socio-demographic parameters. Binary logistic regression was applied to study the effect of predictor variables in determining QOL. $\mathrm{P}$ value $<0.05$ was considered as statistically significant. IEC of Agartala Government Medical College has approved this study.

\section{Results}

Overall QOL was found to be good in $46.2 \%$ of the geriatric subjects. Marginally higher proportion of the subjects from ethnic origin had better quality of life than the nonethnic but was not significant. The study subjects perceived physical health as the most important factor [mean (SD) score 73.18 (9.65)] and social health as the least [mean (SD) score 27.5 (6.43)] for QOL. It was found that $52.9 \%$ of the study subjects were enjoying good QOL in the domain of environment and $37.3 \%$ in the social domain.

Regarding socio-demographic parameters, mean (SD) age of the study subjects was 69.67 ( \pm 8.8$)$ yr. The study shows female preponderance of $53.3 \%$ and majority $(86.2 \%)$ followed Hindu religion. 72\% study subjects were married, $41.8 \%$ belonged to scheduled tribe i.e., of ethnic origin. $66.1 \%$ were illiterate, $53.3 \%$ were unemployed. Majority $(72 \%)$ of the study subjects belonged to joint families, $67.6 \%$ were living in kutcha houses, $36.4 \%$ of the study subjects belonged to lower middle class socioeconomic status and 46.7\% subjects possessed APL category ration cards (Table 1 ).

Table 1. Socio-demographic profile of the study population $(n=225)$.

\begin{tabular}{|c|c|c|}
\hline Variables & Sub-groups & Frequency (\%) \\
\hline Age & $\begin{array}{l}60-69 \text { yrs. } \\
>69-80 \text { yrs. } \\
>80 \text { yrs. }\end{array}$ & $\begin{array}{l}126(56) \\
62(27.6) \\
37(16.4)\end{array}$ \\
\hline Sex & $\begin{array}{c}\text { Male } \\
\text { Female }\end{array}$ & $\begin{array}{l}105(46.7) \\
120(53.3)\end{array}$ \\
\hline Marital status & $\begin{array}{c}\text { Married } \\
\text { Widow/widower } \\
\text { Unmarried } \\
\text { Separated }\end{array}$ & $\begin{array}{l}162(72) \\
59(26.2) \\
02(0.9) \\
02(0.9)\end{array}$ \\
\hline Religion & $\begin{array}{l}\text { Hindu } \\
\text { Muslim } \\
\text { Christian } \\
\text { Others }\end{array}$ & $\begin{array}{l}194(86.2) \\
03(1.3) \\
27(12) \\
01(0.4)\end{array}$ \\
\hline Caste & $\begin{array}{c}\text { General caste } \\
\text { Scheduled caste } \\
\text { Scheduled tribe } \\
\text { Other backward community }\end{array}$ & $\begin{array}{l}43(19.1) \\
41(18.2) \\
94(41.8) \\
47(20.9)\end{array}$ \\
\hline Literacy & $\begin{array}{c}\text { Illiterate } \\
\text { Primary } \\
\text { Secondary } \\
\text { Graduate and above }\end{array}$ & $\begin{array}{l}151(67.1) \\
57(25.3) \\
09(4) \\
08(3.6)\end{array}$ \\
\hline Occupation & $\begin{array}{c}\text { Housewife } \\
\text { Service holder } \\
\text { Unemployed } \\
\text { Retired } \\
\text { Businessman } \\
\text { Others }\end{array}$ & $\begin{array}{c}31(13.8) \\
04(1.8) \\
120(53.3) \\
15(6.7) \\
26(11.6) \\
29(12.9)\end{array}$ \\
\hline Type of family & $\begin{array}{c}\text { Nuclear } \\
\text { Joint }\end{array}$ & $\begin{array}{c}63(28) \\
162(72)\end{array}$ \\
\hline Socioeconomic status(BG Prasad scale 2019) & $\begin{array}{l}\text { Upper class } \\
\text { Upper middle class } \\
\text { Middle class } \\
\text { Lower middle class }\end{array}$ & $\begin{array}{c}14(6.2) \\
37(16.4) \\
54(24) \\
82(36.4)\end{array}$ \\
\hline Type of ration card & $\begin{array}{l}\text { Lower class } \\
\text { APL } \\
\text { BPL }\end{array}$ & $\begin{array}{l}38(16.9) \\
105(46.7) \\
120(53.3)\end{array}$ \\
\hline
\end{tabular}

Chief complaints reported by the study population are shown in Table 2. On clinical examination $23.9 \%$ of the study subjects were normotensive, $30.7 \%$ pre-hypertensive, $25.8 \%$ stage I and $14.2 \%$ stage II hypertensive. Majority $(68 \%)$ of the study subjects were euglycaemic followed by $19.1 \%$ prediabetic and $12.9 \%$ diabetic. Among all $53.3 \%$ had normal BMI.

Domain-wise quality of life of the study subjects as per WHO QOL BREF shows majority i.e., $52.9 \%$ were enjoying good QOL in environmental domain, followed by physical domain (51.1\%), psychological domain (40\%) and social domain $(37.3 \%)$ (Table 3).

Subjects aged either 70 yr. or less had significantly higher QOL in physical and social domains than those aged $>70 \mathrm{yr}$. $(\mathrm{P}<0.05)$. Male subjects had significantly higher QOL in physical and psychological domains than the females. It also showed that subjects belonging to ethnic origin had 
significantly higher QOL in social domain than those of non-ethnic origin $(\mathrm{P}<0.05)$. Subjects who were Hindu had higher QOL in all four domains than those belonging to other religious groups, though these were not significant. Subjects living with spouse had significantly higher QOL in all four domains than those living singly. Higher

Table 2. Chief complaints reported by the geriatric study population $(n=225)$.

\begin{tabular}{lc} 
Chief complaints & Frequency (\%) \\
Joint pain & $50(22.2)$ \\
Breathing problem & $09(4.0)$ \\
\hline Tooth ache and loosening of teeth & $07(3.1)$ \\
Diminution of vision and other eye problems & $14(6.2)$ \\
\hline Generalized body ache & $21(9.3)$ \\
Low backache & $09(4.0)$ \\
\hline Tingling and numbness over limbs & $08(3.6)$ \\
Heartburn and acidity & $15(6.7)$ \\
\hline Sleeplessness & $12(5.3)$ \\
Generalized weakness & $40(17.8)$ \\
\hline Reeling of head & $14(6.2)$ \\
Lack of appetite & $21(9.3)$ \\
\hline Diminished hearing & $05(2.2)$ \\
\hline
\end{tabular}

QOL in all four domains was enjoyed by economically independent and literate subjects though statistically not significant $(\mathrm{P}>0.05)$ (Table 4).

Age, sex, marital status, literacy, economic condition, type of family and type of ration card possessed by the study subjects were significantly associated with their QOL $(\mathrm{P}<0.05)$ [*Fisher's exact test] (Table 5).

Binary logistic regression analysis shows that female subjects had $45.5 \%$ less-

Table 3. Domain wise quality of life of the study subjects as per WHO QOL BREF $(n=225)$.

\begin{tabular}{lrl} 
Domain of quality of life & $\begin{array}{r}\text { Quality of life } \\
\text { Good }\end{array}$ \\
\hline Poor
\end{tabular}

Table 4. Quality of life in different domains by socio-demographic parameters $(n=225)$.

\begin{tabular}{|c|c|c|c|c|}
\hline Domains $\rightarrow$ & Physical & Psychological & Social & Environment \\
\hline Age $\leq 70 \mathrm{yr}$ & $74.41(9.440)$ & $64.60(9.317)$ & $28.51(6.882)$ & $58.97(8.667)$ \\
\hline Age $>70 \mathrm{yr}$ & $71.62(9.734)$ & $62.26(9.235)$ & $26.30(5.601)$ & $59.07(9.334)$ \\
\hline $\mathrm{t}$-value & 2.176 & 1.878 & 2.585 & 0.083 \\
\hline P-value & 0.031 & 0.062 & 0.010 & 0.933 \\
\hline Male sex & $74.76(9.108)$ & $65.03(9.908)$ & $28.11(6.456)$ & $59.73(9.708)$ \\
\hline Female sex & $71.80(9.932)$ & $62.30(8.641)$ & $27.03(6.393)$ & $58.38(8.213)$ \\
\hline t-value & 2.319 & 2.207 & 1.259 & 1.130 \\
\hline P-value & 0.021 & 0.028 & 0.209 & 0.260 \\
\hline Ethnic origin & $73.23(9.331)$ & $63.83(9.475)$ & $28.72(6.425)$ & $58.13(9.669)$ \\
\hline Non ethnic origin & $73.15(9.907)$ & $63.39(9.262)$ & $26.69(6.323)$ & $59.65(8.370)$ \\
\hline t-value & 0.068 & 0.348 & 2.367 & 1.229 \\
\hline P-value & 0.946 & 0.728 & 0.019 & 0.220 \\
\hline Hindu religion & $73.47(9.584)$ & $63.90(9.343)$ & $28.77(5.881)$ & $59.39(8.694)$ \\
\hline Other religions & 71.35 (10.018) & $61.55(9.161)$ & $27.34(6.507)$ & $56.65(10.229)$ \\
\hline t-value & 1.136 & 1.303 & 1.154 & 1.593 \\
\hline P-value & 0.257 & 0.194 & 0.250 & 0.113 \\
\hline Living with spouse & $74.99(9.127)$ & $65.32(9.474)$ & $28.75(6.681)$ & $60.11(8.615)$ \\
\hline Living singly & $68.63(9.488)$ & $59.19(7.378)$ & $24.50(4.536)$ & $56.25(9.234)$ \\
\hline t-value & 4.669 & 4.644 & 4.670 & 2.972 \\
\hline P-value & 0.000 & 0.000 & 0.000 & 0.003 \\
\hline Illiterate & $72.85(9.268)$ & $62.94(8.833)$ & $27.02(6.213)$ & $58.41(9.064)$ \\
\hline Literate & 73.86 (10.418) & $64.86(10.220)$ & 28.59 (6.774) & $60.24(8.632)$ \\
\hline t-value & 0.742 & 1.457 & 1.733 & 1.447 \\
\hline P-value & 0.459 & 0.147 & 0.084 & 0.149 \\
\hline Dependent & $72.60(9.873)$ & $63.20(9.458)$ & $27.11(6.249)$ & $58.77(8.968)$ \\
\hline Independent & $74.81(8.868)$ & $64.61(8.969)$ & 28.75 (6.827) & $59.69(8.927)$ \\
\hline t-value & 1.516 & 0.993 & 1.687 & 0.680 \\
\hline P-value & 0.131 & 0.322 & 0.093 & 0.497 \\
\hline
\end{tabular}


er chance of having good QOL than males and it was statistically significant [95\% $\mathrm{CI}=0.230-0.901 ; \mathrm{P}=0.024]$. Subjects aged more than 70 yr. had $43.5 \%$ lesser chance of having good QOL than those aged 70 yrs. or less $[95 \% \quad \mathrm{CI}=0.207-0.912$; $\mathrm{P}=0.027$ ] similarly subjects living singly had 35.3\% lesser chance of having good QOL than those living with their spouse [95\% CI $=0.164-0.761 ; \mathrm{P}=0.008]$. The rest did not attain the level of statistical significance (Table 6).

\section{Discussion}

This cross-sectional study was conducted after approval by institutional ethics committee of Agartala Govt. Medical College and getting written informed consent. The present study has found that only $46.2 \%$ of the elderly subjects were enjoying good QOL. This is at par with the result of the study conducted by Dasgupta A et al. ${ }^{11}$ where $45.1 \%$ of the elderly had good QOL.
In a study conducted by Shah $\mathrm{V}$ et al. ${ }^{12}$ $3.3 \%$ of the study subjects had fair, $46 \%$ had good and 50.8\% had excellent QOL, but none of them had poor QOL. On the other hand, Qadri SS et $a l .{ }^{4}$ in their study found that $68.2 \%$ of the elderly subjects had good QOL, 30.9\% had average and $0.9 \%$ had poor QOL. These differences may be because the studies were conducted in different settings.

Highest proportion of the study subjects i.e., $52.9 \%$ had good QOL in the environ-

Table 5. Quality of life by socio-demographic parameters of the geriatric subjects $(n=225)$.

\begin{tabular}{|c|c|c|c|c|}
\hline Parameters & Subgroups & ( & & Significance \\
\hline & & Good & Poor & \\
\hline Age group & $\begin{array}{l}\leq 70 \mathrm{yr} \\
>70 \mathrm{yr}\end{array}$ & $\begin{array}{l}77(53.1 \%) \\
27(33.8 \%)\end{array}$ & $\begin{array}{l}68(46.9 \%) \\
53(66.3 \%)\end{array}$ & $\begin{array}{l}\chi^{2}=7.009 \\
P=0.008\end{array}$ \\
\hline Sex & $\begin{array}{c}\text { Male } \\
\text { Female }\end{array}$ & $\begin{array}{l}59(56.2 \%) \\
45(37.5 \%)\end{array}$ & $\begin{array}{l}46(43.8 \%) \\
75(62.5 \%)\end{array}$ & $\begin{array}{l}\chi^{2}=7.870 \\
P=0.005\end{array}$ \\
\hline Ethnicity & $\begin{array}{c}\text { Ethnic } \\
\text { Non-ethnic }\end{array}$ & $\begin{array}{l}44(46.8 \%) \\
60(45.8 \%)\end{array}$ & $\begin{array}{l}50(53.2 \%) \\
71(54.2 \%)\end{array}$ & $\begin{array}{l}\chi^{2}=0.022 \\
P=0.881\end{array}$ \\
\hline Caste & $\begin{array}{c}\text { General caste } \\
\text { Scheduled caste } \\
\text { Scheduled tribe } \\
\text { Other backward class }\end{array}$ & $\begin{array}{l}21(48.8 \%) \\
20(48.8 \%) \\
44(46.8 \%) \\
19(40.4 \%)\end{array}$ & $\begin{array}{l}22(51.2 \%) \\
21(51.2 \%) \\
50(53.2 \%) \\
28(59.6 \%)\end{array}$ & $\begin{array}{l}\chi^{2}=0.875 \\
P=0.832\end{array}$ \\
\hline Literacy & $\begin{array}{c}\text { Illiterate } \\
\text { Primary educated } \\
\text { Secondary educated } \\
\text { Graduate and above }\end{array}$ & $\begin{array}{l}62(41.1 \%) \\
29(50.9 \%) \\
05(55.6 \%) \\
08(100 \%)\end{array}$ & $\begin{array}{c}89(58.9 \%) \\
28(49.1 \%) \\
04(44.4 \%) \\
00(0 \%)\end{array}$ & $\begin{array}{l}{ }^{*} \chi^{2}=12.300 \\
P=0.005\end{array}$ \\
\hline Marital status & $\begin{array}{l}\text { Living with spouse } \\
\text { Living singly }\end{array}$ & $\begin{array}{l}90(55.9 \%) \\
14(21.9 \%)\end{array}$ & $\begin{array}{l}71(44.1 \%) \\
50(78.1 \%)\end{array}$ & $\begin{array}{c}\chi^{2}=21.330 \\
P=0.000\end{array}$ \\
\hline Economic condition & $\begin{array}{l}\text { Dependent } \\
\text { Independent }\end{array}$ & $\begin{array}{l}60(39.7 \%) \\
44(59.5 \%)\end{array}$ & $\begin{array}{l}91(60.3 \%) \\
30(40.5 \%)\end{array}$ & $\begin{array}{l}\chi^{2}=7.773 \\
P=0.007\end{array}$ \\
\hline Type of family & $\begin{array}{l}\text { Nuclear } \\
\text { Joint }\end{array}$ & $\begin{array}{l}36(57.1 \%) \\
68(42.0 \%)\end{array}$ & $\begin{array}{l}27(42.9 \%) \\
94(58.0 \%)\end{array}$ & $\begin{array}{l}\chi^{2}=4.198 \\
P=0.040\end{array}$ \\
\hline Type of ration card & $\begin{array}{l}\text { BPL and similar } \\
\text { APL }\end{array}$ & $\begin{array}{l}59(56.2 \%) \\
45(37.5 \%)\end{array}$ & $\begin{array}{l}46(43.8 \%) \\
75(62.5 \%)\end{array}$ & $\begin{array}{l}\chi^{2}=7.870 \\
P=0.005\end{array}$ \\
\hline
\end{tabular}

*Fisher's exact test.

Table 6. Binary logistic regression analysis predicting quality of life of the study population (n=225).

\begin{tabular}{|c|c|c|c|}
\hline Variables & & OR (95\% CI) & P-value \\
\hline Sex & $\begin{array}{l}\text { Male } \\
\text { Female }\end{array}$ & $0.455(0.230-0.901)$ & 0.024 \\
\hline Age group & $\begin{array}{l}\leq 70 \mathrm{yrs} \\
>70 \mathrm{yrs}\end{array}$ & $\begin{array}{c}1 \\
0.435(0.207-0.912)\end{array}$ & 0.027 \\
\hline Marital status & $\begin{array}{l}\text { Living with spouse } \\
\text { Living singly }\end{array}$ & $\begin{array}{c}1 \\
0.353(0.164-0.761)\end{array}$ & 0.008 \\
\hline Literacy & $\begin{array}{l}\text { Illiterate } \\
\text { Literate }\end{array}$ & $\begin{array}{c}1 \\
1.064(0.517-2.188)\end{array}$ & 0.867 \\
\hline Socioeconomic status & $\begin{array}{l}\text { Upper class } \\
\text { Lower class }\end{array}$ & $\begin{array}{c}1 \\
0.545(0.087-3.417)\end{array}$ & 0.517 \\
\hline Type of family & $\begin{array}{l}\text { Nuclear } \\
\text { Joint }\end{array}$ & $0.558(0.289-1.076)$ & 0.081 \\
\hline Economic condition & $\begin{array}{l}\text { Independent } \\
\text { Dependent }\end{array}$ & $0.670(0.310-1.447)$ & 0.308 \\
\hline Type of ration card & $\begin{array}{l}\text { BPL and similar } \\
\text { APL }\end{array}$ & $\begin{array}{c}1 \\
1.007(0.164-6.180)\end{array}$ & 0.994 \\
\hline
\end{tabular}


mental domain whereas only $37.3 \%$ of the subjects had good QOL in the social domain. Pravin and Rani ${ }^{13}$ in their study also had similar findings in the environmental domain. This may be because the elderly people living in rural areas were relatively more satisfied about their natural environment. Mudey et al. ${ }^{14}$ in their study concluded that the QOL of the rural elderly was good in the physical and psychological domains whereas QOL among the elderly of the urban slums was better in areas of social relationship and environmental domains.

In the present study mean (SD) age of the study subjects was found to be 69.67 (8.8) yr., which is like the findings of a study conducted in urban Mangalore, India, where the mean age was $68.62 \pm 6.59 \mathrm{yr}^{15}$ Majority (56\%) belonged to 60-69 yr. age group. Ghosh et al. ${ }^{2}$ also found $68.25 \%$ of the subjects to be in the age group of 60-69 yr. Present study revealed that subjects aged 70 yrs. or less had significantly higher QOL in physical and social relationship domain than the older.

Present study showed female preponderance $(53.3 \%)$, which is comparable with the studies conducted by Sowmiya et al. ${ }^{16}$ where female participants outnumbered males. In the present study significant gender-related differences were found in the physical and psychological domains of QOL scores. The present study also revealed that females had $45.5 \%$ lesser chance of having good QOL as compared to the males $[95 \%$ CI $=0.230$ $0.901 ; \mathrm{P}=0.024]$. Study conducted by Lokare et al. ${ }^{17}$ at Vidyanagar, Karnataka showed that mean score of male and female differed significantly only in the physical domain but not in others.

In the present study the subjects were predominantly Hindu ( $86.2 \%$ ) by religion. In the studies conducted by Akbar et al. ${ }^{18}$ and Karmakar et al. ${ }^{19}$, majorities of the subjects were Hindu by religion. In the present study relatively higher proportion of the subjects of Muslim religion had over all good quality of life as compared to the rest. Subjects belonging to Hindu religion had higher quality of life than the non-Hindu in all four domains of QOL, though statistically it was not significant $(\mathrm{P}>0.05)$. Study conducted by Karmakar et al. ${ }^{19}$ showed significant association between QOL and religion of the respondents in the psychological domain.

In the present study lower middle class constituted $36.4 \%$ of the subjects which is contrary to the finding of Karmakar et al. ${ }^{19}$ where lower middle class constituted only $14.5 \%$. Karmakar et al. ${ }^{19}$ also found socioeconomic status to have significant associations with psychological and environmental domains of the QOL. Study conducted by Nilsson et al..$^{20}$ in Bangladesh also reported economic status as a significant determinant of QOL among the elderly.

In the present study good QOL was found among the subjects living with their spouse and it was at par with the findings of a study conducted by Qadri et al. ${ }^{4}$ Sowmiya et al. ${ }^{16}$ also reported better mean QOL score in all the domains among the elderly subjects except the psychological domain.

Present study showed that overall QOL increased with the increment in the level of education. Literacy showed significant association with the overall QOL of an individual but not in domain wise QOL. In a similar study, Qadri SS et al. ${ }^{4}$ also reported literacy of an individual to be significantly associated with QOL.

In the present study occupation of the participants had significant association with their QOL, which was at par with the findings of Rajput et al. ${ }^{21}$ Karmakar et al. ${ }^{19}$ in their study have shown occupation to have significant association in the environmental domain of QOL.

This study revealed that $72 \%$ of the study participants were from joint families, which was at par with the findings of Karmakar et al. ${ }^{19}$ and Rajput, ${ }^{21}$ where $77.6 \%$ and $73.8 \%$ of the subjects were from the joint families respectively. Joshi $\mathrm{K}$ et al. ${ }^{22}$ observed better social support to the elderly with the increment in household size, but the present study did not support this finding.

\section{Conclusions}

Geriatric people living in rural areas of West Tripura district have got poor overall health related quality of life. Age, sex, literacy, marital status, socioeconomic status, relationship with family members and type of ration card were significantly associated with their QOL. Living with spouse, young old age and male sex were the predictors of perceived good QOL in this population. Ethnic subjects had better QOL than the non-ethnic.

\section{References}

1. Park K. Park's textbook of preventive and social medicine. 24th ed. Jabalpur: M/s Banarsidas Bhanot; 2017. Edn 16 p 38 .

2. Ghosh S, Sarker G, Bhattacharya K, et al. Quality of life in geriatric population in a community development block of Kishanganj, Bihar, India. J Krishna Inst Med Sci Univ 2017;6:33-41.
3. Hameed S, Brahmbatt KR, Patil DC, et al. Quality of life among the geriatric population in Dakshina Kannada. Karnataka, India. Global J Med Public Health 2014;3:1-5.

4. Qadri SS, Ahluwalia S, Ganai AM, et al. H. An epidemiological study on quality of life among rural elderly population of northern India. Int $\mathrm{J}$ Med Sci Public Health 2013;2:514-22.

5. Caring for Our Elders. Early responses, India ageing report. New Delhi: UNPF; 2017. 105p. Report No: 4.

6. Elderly in India - Profile and Programmes 2016. New Delhi: Social Statistics Office, Government of India; 2016 Feb. Available from: http://mospi.nic.in/sites/default/files/pub lication_reports/ElderlyinIndia_2016.pd f Accessed: 4th March 2019.

7. Elderly in India: 2016. New Delhi: Ministry of Statistics and Programme Implementation, 2016. Available from: ElderlyinIndia_2016.pdf (mospi.nic.in). Accessed: 7th March 2019.

8. Riffenburgh RH. Statistics in medicine. 3rd edition. USA: Elsevier; 2012. 378 p.

9. Kumar G, Majumder A, Pavithra G. Quality of life (QOL) and its associated factors using WHOQOL-BREF among elderly in urban Puducherry, India. J Clin Diagn Res 2014;8:54-7.

10. WHOQOL-BREF Introduction, administration, scoring and generic version of the assessment Field Trial Version, 1996 December. Programme on Mental Health, World Health Organization Geneva. 2018, Page 5. Available from: https://www.who.int/mental_health/med ia/en/76.pdf Accessed: 4th March 2019.

11. Dasgupta A, Pan T, Paul B, et al. Quality of life of elderly people in a rural area of West Bengal: a community based study. Med J Dy Patil Vidyapeeth 2018;11:52731. Available from: https://www. mjdrdypv.org/article. asp?issn=25898302 ; year $=2018$; volume $=11$; issue $=6$; sp age $=527$; epage $=531$; aulast $=$ Dasgupta Accessed: 8th March 2019.

12. Shah V, Christian D, Prajapati A, et al. Quality of life among elderly population residing in urban field practice area of a tertiary care institute of Ahmedabad city, Gujarat. J Family Med Prim Care 2017;6:10-105.

13. Praveen V, Rani MA. Quality of life among elderly in a rural area. Int J Commun Med Public Health 2016; 3:754-7.

14. Mudey A, Ambekar S, Goyal R, et al. Assessment of quality of life among rural and urban elderly population of Wardha district, Maharashtra, India. Ethno Med 2011;5:89-93. 
15. Devraj S, D'mello MK. Determinants of quality of life among the elderly population in urban areas of Mangalore, Karnataka. J Geriatr Ment Health 2019; 6:94-8.

16. Sowmiya K. A study on quality of life in elderly population in Mettupalayam, a rural area of Tamilnadu. Nat $\mathrm{J}$ Res Comm Med 2012;1:123-77.

17. Lokare L, Nekar MS, Mahesh V. Quality of life and restricted activity days among the old aged. Int $\mathrm{J}$ Biol Med Res 2011;2:1162-4.
18. Akbar F, Kumar M, Das N, et al. Quality of life (QOL) among geriatric population in Siliguri sub-division of district Darjeeling, West Bengal. Nat J Res Com Med 2013;2:17-22.

19. Karmakar N, Datta A, Nag K, Tripura K. Quality of life among geriatric population: A cross-sectional study in a rural area of Sepahijala district, Tripura. Indian J Public Health 2018; 62:95-9.

20. Nilsson J, Rana AK, Kabir ZN. Social capital and quality of life in old age: results from a cross-sectional study in rural Bangladesh. J Ageing Health 2006; 18:419-34.

21. Rajput M, Pinki, Kumar S, et al. Quality of life of geriatric population in rural block of Haryana. Public Health Rev-Int J Public Health Res 2019;6:192-9.

22. Joshi K, Kumar R, Avasthi A. Morbidity profile and its relationship with disability and psychological distress among elderly people in Northern India. Int J Epidemiol 2003;32:978-87. 